\title{
PENGARUH BERKUMUR LARUTAN PROBIOTIK TERHADAP PH SALIVA SISWA SMP NEGERI 13 BANJARBARU
}

\author{
Muhammad Fajar Nursyamsi' ${ }^{1}$, Danan $^{2}$, Siti Sab'atul Habibah ${ }^{3}$ \\ 1,2 Poltekkes Kemenkes Banjarmasin Jurusan Keperawatan Gigi \\ Email : fajarnursyamsi@gmail.com
}

\section{ABSTRAK \\ LATAR BELAKANG :}

Karies gigi merupakan kerusakan jaringan keras gigi yang disebabkan oleh asam yang ada dalam karbohidrat melalui perantara mikroorganisme yang ada dalam saliva. Mikroorganisme yang ada dalam mulut yang mampu menghasilkan asam melalui peragian yaitu Streptococcus dan Laktobasil.

Tujuan Umum Untuk mengetahui pengaruh berkumur larutan probiotik terhadap pH saliva pada siswa SMP Negeri 13 Banjarbaru. Tujuan khusus 1) Untuk mengetahui pH saliva sebelum berkumur larutan probiotik pada siswa SMP Negeri 13 Banjarbaru. 2) Untuk mengetahui $p H$ saliva sesudah berkumur larutan probiotik siswa SMP Negeri 13 Banjarbaru. 3) Untuk mengetahui pengaruh berkumur larutan probiotik terhadap $\mathrm{pH}$ saliva siswa SMP Negeri 13 Banjarbaru.

Metode penelitiannya eksperimen semu, dimana kegiatan percobaan ini bertujuan untuk mengetahui suatu gejala atau pengaruh yang timbul sebagai akibat dari adanya perlakuan tertentu. Variabel Bebas (Independen): Berkumur larutan probiotik, Variabel Terikat (Dependen): $\mathrm{pH}$ saliva

Hasil uji statistik menunjukan bahwa rata-rata $\mathrm{pH}$ saliva sebelum perlakuan adalah 5,935 sedangkan rata-rata $\mathrm{pH}$ saliva sesudah diberikan perlakuan adalah 6,867. Uji T berpasangan menghasilkan nilai $p$ pada kolom sig. (2-tailled) $=0,000$. Pada pengujian signifikan dengan nilai kepercayaan $95 \%$ atau tingkat kesalahan $5 \%$ maka dapat disimpulkan nilai $p$ value (nilai probabilitas) dari uji tersebut $(p=0,000<$ $\alpha=0,05)$, , adanya pengaruh berkumur larutan probiotik terhadap $\mathrm{pH}$ saliva pada siswa SMP Negeri 13 Banjarbaru.

Kata Kunci : Larutan Probiotik, $\mathrm{pH}$ saliva 


\section{PENDAHULUAN}

Karies gigi masih merupakan masalah utama di Indonesia, dimana hampir $90 \%$ dari jumlah penduduk bermasalah dengan kesehatan gigi dan mulutnya. Menurut hasil Riskesdas tahun 2013, indeks DMF-T (indeks untuk menilai gigi permanen) Indonesia sebesar 4,6 meliputi komponen D-T 1,6, komponen M-T 2,9, dan komponen F-T 0,08. Ini berarti rerata jumlah kerusakan gigi per orang (tingkat keparahan gigi per orang) adalah 4,6 gigi, meliputi 1,6 gigi yang berlubang, 2,9 gigi yang dicabut dan 0,08 gigi yang ditumpat, hal ini menurut WHO masih tinggi (Surarti AML, Jovina TA, Tjahja IN, 2017).

Di Indonesia ada tiga provinsi dengan prevalensi masalah gigi dan mulut yang cukup tinggi ( $\geq 35 \%)$, yaitu Sulawesi Selatan $(36,2 \%)$, Kalimantan Selatan $(36,1)$ dan Sulawesi Tengah (35,6\%). Prevalensi karies aktif di Provinsi Kalimantan Selatan pada tahun 2013 adalah 66,0\% yang menunjukkan peningkatan prevalensi terjadinya karies aktif pada penduduk Kalimantan Selatan dibandingkan tahun 2007 yaitu 49,3\% (Balitbangkes, 2013).

Berdasarkan data sekunder dari hasil penelitian terdahulu di SMP Negeri 13 Banjarbaru yang dilakukan oleh Risna Amelia tahun 2018 dari 53 orang didapat ratarata plak skor sebelum berkumur teh hitam sebesar 2,98 sedangkan sebelum berkumur teh hijau sebesar 2,74. Dari penelitian Sandi Oktavianor tahun 2017 dengan jumlah sampel 50 responden didapatkan hasil OHI-S dengan kategori baik 2 orang atau $4 \%$, kategori sedang 24 orang atau $48 \%$ dan kategori buruk 24 orang atau $48 \%$. Pada hasil penelitian Salehana dari 90 siswa terdapat 13 siswa dengan kategori DMF$\mathrm{T}$ rendah (14,44\%), 37 siswa dengan DMF-T sedang $(41,11 \%)$ dan 40 siswa yang memiliki DMF-T dengan kategori tinggi $(44,44 \%)$.

Hasil studi pendahuluan yang dilakukan oleh peneliti di SMP Negeri 13 Banjarbaru dari 10 siswa didapatkan hasil rata-rata $p H$ Saliva 6,45.

Berdasarkan latar belakang diatas, maka peneliti bermaksud untuk menganalisis efektifitas larutan kumur probiotik sebagai alternatif pengganti obat kumur kimiawi, yang diharapkan bisa mengembalikan $\mathrm{pH}$ normal saliva sehingga bakteri penyebab karies gigi terutama Streptococcus mutans tidak melekat pada gigi dan tidak membentuk koloni sehingga tidak terjadi proses demineralisasi email dan mengurangi tingkat kerusakan gigi. Dapat dirumuskan masalah sebagai berikut "Apakah ada pengaruh berkumur larutan probiotik terhadap potential of hidrogent $(p H)$ saliva pada siswa SMP Negeri 13 Banjarbaru?". Tujuan Umum untuk mengetahui pengaruh berkumur larutan probiotik terhadap $\mathrm{pH}$ saliva pada siswa SMP Negeri 13 Banjarbaru.

\section{BAHAN DAN METODE}

Jenis penelitian ini adalah penelitian eksperimen semu dimana kegiatan percobaan ini bertujuan untuk mengetahui suatu gejala atau pengaruh yang timbul sebagai akibat dari adanya perlakuan tertentu Rencana penelitian yang digunakan adalah one group pretest post-test. penelitian ini adalah siswa SMP Negeri 13 Banjarbaru yang berjumlah sebanyak 170 siswa. Variabel Bebas (Independen): Berkumur larutan probiotik dan Variabel Terikat (Dependen): $\mathrm{pH}$ saliva. 
HASIL DAN PEMBAHASAN

Hasil peneletian tentang Pengaruh Berkumur Larutan Probiotik Terhadap Ph Saliva Siswa Smp Negeri 13 Banjarbaru dapat dilihat tabel dibawah ini :

Tabel 1 Data Jumlah Siswa Kelas IX A dan IX B SMP Negeri 13 Banjarbaru

\begin{tabular}{l|lc|c|c}
\hline No. & Kelas & Jumlah & Persentase \\
\hline 1 & IX A & 24 & $49,0 \%$ \\
\hline 2 & IX B & 25 & $51,0 \%$ \\
& & 49 & $100 \%$ \\
\hline
\end{tabular}

Dari tabel 1 dapat dilihat bahwa jumlah siswa kelas IX A dan IX B SMP Negeri 13 Banjarbaru sebanyak 49 orang dengan jumlah siswa kelas IX A sebanyak $24(49,0 \%)$ orang dan siswa kelas IX B sebanyak 25 orang $(51,0 \%)$.

Tabel 2 Data Jenis Kelamin Siswa Kelas IX A dan IX B SMP Negeri 13 Banjarbaru.

\begin{tabular}{c|c|c|c|c}
\hline & Frequency & Percent & $\begin{array}{c}\text { Valid } \\
\text { Percent }\end{array}$ & $\begin{array}{c}\text { Cumulative } \\
\text { Percent }\end{array}$ \\
\hline Valid Laki-laki & 25 & 51.0 & 51.0 & 51.0 \\
$\begin{array}{c}\text { Perempua } \\
\mathrm{n}\end{array}$ & 24 & 49.0 & 49.0 & 100.0 \\
Total & 49 & 100.0 & 100.0 & \\
\hline
\end{tabular}

Dari tabel 2 dapat dilihat bahwa jumlah siswa yang menjadi sampel penelitian yaitu 49 orang dengan jumlah laki-laki 25 orang (51\%) dan jumlah perempuan 24 orang $(49 \%)$. 
Tabel 3 Deskripsi Hasil Pengukuran pH Saliva Sebelum Berkumur Larutan Probiotik

\begin{tabular}{l|r|r}
\hline & Statistic & Std. Error \\
\hline Pengukur Mean & 5.935 & .0740 \\
an pH 95\% Confidence Lower Bound & 5.786 & \\
Saliva Interval for Mean Upper Bound & 6.083 & \\
(Sebelum & 6.000 & \\
Median & .5178 & \\
Std. Deviation & 4.6 & \\
Minimum & 6.9 & \\
Maximum & 2.3 & \\
Range & \\
\hline
\end{tabular}

Dari tabel 3 diketahui bahwa nilai maksimum adalah 6,9 dan nilai minimum adalah 4,6 dengan standar devisiasi 0,5178 serta rata-rata $\mathrm{pH}$ saliva sebelum perlakuan pada siswa kelas IX A dan IX B SMP Negeri 13 Banjarbaru adalah 5,935 dengan ini menunjukkan bahwa keadaan $\mathrm{pH}$ saliva sebelum berkumur larutan probiotik adalah keadaan asam.

Tabel 4.4 Deskripsi Hasil Pengukuran pH Saliva Sesudah Berkumur Larutan Probiotik.

\begin{tabular}{lll|c|c}
\hline $\begin{array}{lll}\text { Pengukuran } \\
\text { pH Saliva }\end{array}$ & Mean & 6.867 & .0496 \\
(Sesudah) & 95\% Confidence Lower & 6.768 & \\
& $\begin{array}{l}\text { Interval for } \\
\text { Mean }\end{array}$ & $\begin{array}{r}\text { Bound } \\
\text { Upper } \\
\text { Bound }\end{array}$ & 6.967 & \\
& Median & & 6.800 & \\
& Std. Deviation & .3472 & \\
& Minimum & 5.8 & \\
& Maximum & 7.5 & \\
& Range & 1.7 & \\
\hline
\end{tabular}

Dari tabel 4 diketahui bahwa nilai maksimum adalah 7,5 dan nilai minimum adalah 5,8 dengan standar devisiasi 0,3472 serta rata-rata $\mathrm{pH}$ saliva sesudah perlakuan pada siswa SMP Negeri 13 Banjarbaru adalah 6,867. Dengan ini menunjukkan bahwa keadaan $\mathrm{pH}$ saliva sesudah diberi perlakuan berupa berkumur larutan probiotik awalnya dalam keadaan asam menjadi mendekati netral. 
Tabel 5 Hasil Analisis Statistik dengan Uji Paired T-Test

\begin{tabular}{|c|c|c|c|c|c|c|c|c|}
\hline & \multicolumn{5}{|c|}{ Paired Differences } & \multirow[b]{3}{*}{$\mathrm{t}$} & \multirow{3}{*}{ df } & \multirow{3}{*}{$\begin{array}{l}\text { Sig. } \\
(2- \\
\text { tailed })\end{array}$} \\
\hline & \multirow{2}{*}{ Mean } & \multirow{2}{*}{$\begin{array}{c}\text { Std. } \\
\text { Deviation }\end{array}$} & \multirow{2}{*}{$\begin{array}{l}\text { Std. } \\
\text { Error } \\
\text { Mean }\end{array}$} & \multicolumn{2}{|c|}{$\begin{array}{c}95 \% \\
\text { Confidence } \\
\text { Interval of the } \\
\text { Difference }\end{array}$} & & & \\
\hline & & & & Lower & Upper & & & \\
\hline $\begin{array}{ll}\text { Pair } & \text { Pengukuran } \\
1 & \text { pH Saliva } \\
& \text { (Sesudah) - } \\
& \text { Pengukuran } \\
& \text { pH Saliva } \\
& \text { (Sebelum) }\end{array}$ & .9327 & .3619 & .0517 & .8287 & 1.0366 & 18.038 & 48 & .000 \\
\hline
\end{tabular}

tabel 5 diketahui bahwa hasil analisis berupa rata-rata $\mathrm{pH}$ saliva sebelum perlakuan adalah 5,935 dengan standar devisiasi 0,5178 sedangkan rata-rata $\mathrm{pH}$ saliva sesudah diberikan perlakuan adalah 6,867 dengan standar devisiasi 0,3472. Uji T berpasangan menghasilkan nilai $p$ pada kolom sig. (2-tailled) $=0,000$. Pada pengujian signifikan dengan nilai kepercayaan $95 \%$ atau tingkat kesalahan $5 \%$ maka dapat disimpulkan nilai $p$ value (nilai probabilitas) dari uji tersebut $(p=0,000<\alpha=0,05)$, dengan kata lain $\mathrm{H}_{0}$ ditolak dan $\mathrm{H}_{\mathrm{a}}$ diterima karena $p=0,000$ lebih kecil dari $\alpha=0,05$, maka ada pengaruh berkumur larutan probiotik terhadap $\mathrm{pH}$ saliva pada siswa SMP Negeri 13 Banjarbaru.

\section{PEMBAHASAN}

Berdasarkan hasil penelitian, jumlah siswa kelas IX A dan IX B SMP Negeri 13 Banjarbaru sebanyak 49 orang dengan jumlah siswa kelas IX A sebanyak $24(49,0 \%)$ orang dan siswa kelas IX B sebanyak 25 orang (51,0\%). Sedangkan jumlah siswa yang menjadi sampel penelitian yaitu 49 orang dengan jumlah laki-laki 25 orang $(51 \%)$ dan jumlah perempuan 24 orang (49\%). diketahui bahwa nilai maksimum adalah 6,9 dan nilai minimum adalah 4,6 dengan standar devisiasi 0,5178 serta rata-rata $p H$ saliva sebelum perlakuan pada siswa kelas IX A dan IX B SMP Negeri 13 Banjarbaru adalah 5,935 dengan ini menunjukkan bahwa keadaan $\mathrm{pH}$ saliva sebelum berkumur larutan probiotik adalah keadaan asam. Serta diketahui bahwa nilai maksimum adalah 7,5 dan nilai minimum adalah 5,8 dengan standar devisiasi 0,3472 serta rata-rata $p H$ saliva sesudah perlakuan pada siswa SMP Negeri 13 Banjarbaru adalah 6,867. 
Dengan ini menunjukkan bahwa keadaan $\mathrm{pH}$ saliva sesudah diberi perlakuan berupa berkumur larutan probiotik awalnya dalam keadaan asam menjadi mendekati netral. hasil analisis berupa rata-rata $\mathrm{pH}$ saliva sebelum perlakuan adalah 5,935 dengan standar devisiasi 0,5178 sedangkan rata-rata $\mathrm{pH}$ saliva sesudah diberikan perlakuan adalah 6,867 dengan standar devisiasi 0,3472. Uji T berpasangan menghasilkan nilai $p$ pada kolom sig. (2-tailled) $=0,000$. Pada pengujian signifikan dengan nilai kepercayaan $95 \%$ atau tingkat kesalahan 5\% maka dapat disimpulkan nilai $p$ value (nilai probabilitas) dari uji tersebut $(p=0,000<\alpha=0,05)$, dengan kata lain $\mathrm{H}_{0}$ ditolak dan $\mathrm{H}_{a}$ diterima karena $p=0,000$ lebih kecil dari $\alpha=0,05$, maka ada pengaruh berkumur larutan probiotik terhadap $\mathrm{pH}$ saliva

\section{DAFTAR PUSTAKA}

Amelia R, 2018. Perbedaan Berkumur Dengan Larutan Teh Hitam dengan Teh Hijau Terhadap Penurunan Plak Skor pada Siswa Kelas VIII SMPN 13 Banjarbaru. Poltekkes Kemenkes Banjarmasin, Banjarbaru.

Amerongen AN, 1991. Ludah dan Kelenjar Ludah: Arti bagi kesehatan gigi. Gadjah Mada University Press, Yogyakarta.

Andriani E, 2018. Pengaruh Berkumur Air Rebusan Daun Salam (Syzgium Polyanthum) dengan Konsentrasi 4\% Terhadap Penurunan Plak Indeks pada Siswa SMPN 9 Banjarbaru. Poltekkes Kemenkes Banjarmasin, Banjarbaru.

Anggraini LR, 2018. Pengaruh Berkumur Dengan Larutan Madu Terhadap $p H$ Saliva pada Siswa Kelas VIII MTs Hidayatullah Martapura. Poltekkes Kemenkes Banjarmasin, Banjarbaru.

Ariesta F, 2015. $p H$ meter Manfaat dan Kegunaan untuk Ber-Hidroponik. http://jurnalhidroponik.blogspot.com/2015/01/ph-meter-manfaat-dankegunaan-untuk-ber.html. Diakses November 2018.

Astiti RW, 2010. Perbedaan Volume Saliva Sebelum dan Sesudah Meminum Yogurt Probiotik Yang Mengandung Bifidobacterium animalis Pada Mahasiswa Fakultas Kedokteran Gigi Universitas Padjadjaran. Universitas Padjadjaran, Bandung(ID).

Balitbangkes, 2013. Riset Kesehatan Dasar 2013 Badan Penelitian dan Pengembangan Kesehatan, Kementerian Kesehatan Republik Indonesia, Jakarta.

Depkes RI, 2004. Sistem Kesehatan Nasional, Departemen Kesehatan Republik Indonesia, http://dinkes.bantulkab.go.id/documents/20090721100343-skkn2004.pdf. Diakes November 2017.

-------, 2009. Undang-undang Dasar Republik Indonesia Nomor 36, Departemen Kesehatan Republik Indonesia.

Irfan $\quad$ M, 2014. Tabel Mikroorganisme Bioteknologi. https://newirfanmuhluster.wordpress.com/2014/01/30/tabel-mikroorganismebioteknologi/

Irma IZ, Intan SA, 2013. Penyakit Gigi, Mulut, dan THT. Nuha Medika, Yogyakarta.

Khoerunnisa N, Ningrum FH, Nawangsih CP., 2017. Hubungan Derajat Xerostomia dengan $\mathrm{pH}$ Saliva Pasca Radioterapi Kanker Kepaala Leher. Jurnal Kedokteran Diponegoro Volume 6(2). 983-992.

Kidd EAM, dan Bechal SJ, 1991. Dasar-dasar Karies Penyakit dan Penanggulangannya. Buku Kedokteran EGC, Jakarta. 
Lestari LA, Helmyati S, 2014. Peran Probiotik di Bidang Gizi dan Kesehatan. Gadjah Mada University Press, Yogyakarta.

Machfoedz I, 2008. Menjaga Kesehatan Gigi dan Mulut Anak-Anak dan Ibu Hamil. Fitramaya, Yogyakarta.

Marasabessy FA, 2013. Hubungan Volume dan pH Saliva pada Lansia. Universitas Hasanuddin, Makassar.

Ningsih SU, Restuastuti T, Endriani R, 2016. Gambaran Pengetahuan dan Sikap Menyikat Gigi pada Siswa-siswi dalam Mencegah Karies di SDN 005 Bukit Kapur Dumai. Jom FK Volume 3(2).

Notoadmodjo S, 2010. Metodologi Penelitian Kesehatan. Rineka Cipta, Jakarta.

Oktavianor S, 2017. Hubungan Perilaku Menggosok Gigi dengan OHI-S (Oral Hygiene Index Simpplified) pada Siswa SMPN 13 Banjarbaru. Poltekkes Kemenkes Banjarmasin, Banjarbaru.

Prangdimurti E, 2001. Probiotik dan Efek Perlindungannya Terhadap Kanker Kolon. Institut Pertanian Bogor, Bogor (ID). http://www.rudyct.com/PPS702ipb/03112/endang prangdimurti.htm. Diakses Oktober 2018.

Prasko, 2011. Pengertian saliva, fungsi saliva, dan $\mathrm{pH}$ saliva. http://prasko17.blogspot.com/2011/08/pengertian-saliva-fungsi-saliva-danph.html. Diakses Oktober 2018

Rahmawati I, Said F, Hidayati S, 2015. Perbedaan pH Saliva Antara Sebelum dan Sesudah Mengkonsumsi Minuman Ringan. Jurnal Skala Kesehatan Volume $6(1)$.

Ratnasari DM, 2015. Pengaruh Larutan Kumur Probiotik Terhadap Peningkatan pH Saliva. Universitas Muhammadiyah Surakarta, Surakarta (ID).

Rizqi F, Barid I, Probosari N., 2013. Hubungan pH dan Buffer Saliva dengan Indeks DMF-T pada Siswa Retardasi Mental SLB-C TPA Jember. Artikel IImiah Hasil Penelitian Mahasiswa 2013.

Rizzkiya A, 2015. Perbedaan Nilai pH Plak Sebelum dan Sesudah Berkumur Minuman Probiotik (Kajian pada Anak dengan Penyakit Jantung Kongenital. Universitas Indonesia, Jakarta (ID).

Salehana, 2018. Hubungan Pengetahuan Pemeliharaan Kesehatan Gigi dan Mulut dengan Indeks DMF-T pada Siswa Kelas VII dan VIII SMPN 13 Banjarbaru. Poltekkes Kemenkes Banjarmasin, Banjarbaru.

Samiadi LA, 2017. 7 Makanan Sumber Probiotik, Bakteri Baik untuk Kesehatan. Hello Sehat. https://hellosehat.com/hidup-sehat/nutrisi/7-makanan-sumberprobiotik-bakteri-baik/. Diakses Oktober 2018

Santoso I, 2013. Manajemen Data Untuk Analisis Data Penelitian Kesehatan. Gosyen Publishing, Yogyakarta.

Sinaga A, 2013. Faktor-faktor yang Berhubungan Perilaku Ibu Dalam Mencegah Karies Gigi Anak Usia 1-5 Tahun di Puskesmas Babakan Sari Bandung. Jurnal Darma Agung. Halaman 1-10.

Sugiaman VK, 2014. Manfaat Keasaman Yogurt dalam Pencegahan Karies Gigi. Universitas Kristen Maranatha, Bandung. Vol. 3(2).

Surarti AML, Jovina TA, Tjahja IN, 2017. Pengaruh $(p H)$ Saliva terhadap Terjadinya Karies Gigi pada Anak Usia Prasekolah. Percetakan Negara. Vol. 45(4); 241 248.

Tarigan R, 1990. Karies Gigi. Hipokrates, Jakarta.

Tarigan R, 2013. Karies Gigi, Ed.2. Buku Kedokteran EGC, Jakarta. 